


\section{EDITORIAL} BOARD
Editor-in-Chief

Massimo Cuzzolaro (Roma)

Executive Editors
Ottavio Bosello
(Verona)
Saverio Cinti
(Ancona)
Giovanni Cizza
(Washington)
Paul E. Garfinkel
(Toronto)

\section{Editorial Board}

Gianfranco Adami (Genova)

W. Stewart Agras

(Stanford)

Arnold Andersen (Jowa City)

Maurizio Bellini (Bologna)

C. Laird Birmingham (Vancouver)

Maria Rosa Bollea

(Roma)

Kelly D. Brownell

(New Haven)

Luca Busetto

(Padova)

Michele Carruba

(Milano)

Felipe F. Casanueva

(Santiago de

Compostela)

Francesco Cavagnini (Milano)
Francesco Caviezel (Milano)

Luca Chiovato

(Pavia)

Massimo Clerici (Milano)

Francesco Contaldo

(Napoli)

Peter J. Cooper

(Reading)

Pietro Cugini

(Roma)

Riccardo Dalle Grave

(Verona)

Christopher Dare

(London)

Lorenzo M. Donini

(Roma)

Christopher Fairburn (Oxford)

Angela Favaro

(Padova)

Giovanni Federspil

(Padova)

Manfred M. Fichter

(München)

David M. Garner

(Toledo, Ohio)

Maria G. Gentile (Milano)

Ezio Ghigo

(Torino)

Gian Paolo Guaraldi

(Modena)

Katherine A. Halmi

(New York)

Marcelo Heckier

(Buenos Aires)

Hans W. Hoek

(The Hague)

Philippe Jeammet

(Paris)
Allan S. Kaplan

(Toronto)

Frantisek Krch

(Praha)

Hubert Lacey

(London)

Bryan Lask

(London)

Gabriel Levi

(Roma)

Giovanni Liotti

(Roma)

Claudio Maffeis

(Verona)

Fausto Manara

(Brescia)

Nazario Melchionda

(Bologna)

Enrico Molinari

(Milano)

Mervat Nasser

(London)

Fugen A. Neziroglu

(Great Neck)

Luigi Onnis

(Roma)

Angela Polito

(Roma)

Michel Probst

(Leuven)

Carla E. Ramacciotti (Pisa)

Günther Rathner

(Innsbruck)

Valdo Ricca

(Firenze)

Gabriella Ripa di

Meana

(Roma)

Jan $\mathrm{H}$. Rosenvinge

(Tromsø)
Carlo M. Rotella

(Firenze)

Gerald F.M. Russell

(London)

Paolo Santonastaso

(Padova)

Alessandro Sartorio (Milano)

J. Kevin Thompson

(Tampa)

Josep Toro

(Barcelona)

Janet Treasure

(London)

Walter Vandereycken (Leuven)

Johan Vanderlinden

(Leuven)

Roberto Vettor

(Padova)

Glenn Waller

(London)

Donald A. Williamson

(Baton Rouge)

G. Terence Wilson

(Piscataway)

Jose A. Yaryura Tobias (Great Neck)

\section{Statistical \\ Advisers}

Gianfranco Marano

(Rovigo)

Rocco Micciolo

(Trento)

\section{Editorial Secretary}

Anna Piccinini

(Roma)

\section{Affiliated to the SIS-DCA (Italian Society for the Study of Eating Disorders)}

Executive Committee

Roberto Ostuzzi
(Vicenza) President
Massimo Cuzzolaro
(Roma) Past President
Matteo Balestrieri
(Udine)
Giovanni Caputo
(Roma)

Roberto Ostuzzi

(Vicenza) President

Giancarlo Di Pietro (Napoli)

Fabrizio Jacoangeli

(Roma)

Nazario Melchionda (Bologna)

Alessia Minniti

(Verona)

Pier Eugenio Nebiolo
(Aosta)
Umberto Nizzoli
(Reggio Emilia)
Silvia Perrone
(Lecce)
Romana Schumann
(Bologna)

Ignazio Senatore (Napoli)

Giovanni Spera (Roma)

Giuliano Turrini

(Parma) 
GENERAL INFORMATION
The journal of Eating and Weight Disorders/Studies on Anorexia, Bulimia and Obesity publishes basic research, clinical and theoretical articles on eating disorders and weight-related problems: anorexia nervosa, bulimia nervosa, subthreshold eating disorders, obesity, atypical patterns of eating behaviour and body weight regulation in clinical and non-clinical populations.

The journal features: Review Articles, Original Research Papers, Brief Reports, New Hypotheses, Case Reports, Instruments, Recent Books and Correspondence.

Electronic version of full text is available at our web site: www.kurtis.it

Eating and Weight Disorders/Studies on Anorexia, Bulimia and Obesity is peerreviewed. It is published quarterly by Editrice Kurtis s.r.l. and is covered in Index Medicus, MEDLINE, PsycINFO, SIIC Data Bases, Science Citation Index Expanded (also known as SciSearch ${ }^{\otimes}$ ) and Journal Citation Reports/Science Edition.

Please note the e-mail address of the journal: ewd@kurtis.it

\section{COPYRIGHT}

Submission of a manuscript implies that i) neither the manuscript submitted nor any part of it (except the Abstract) has been published elsewhere before, ii) it is not under consideration for publication elsewhere, iii) its publication has been approved by all coauthors, if any, as well as by the responsible authorities at the institute where the work was carried out, iv) if and when the manuscript is accepted for publication, the authors transfer the copyright to the Publisher, $v$ ) the manuscript will not be published elsewhere in any language without the consent of the copyright holders.

All articles published in this journal are protected by copyright, which covers the exclusive rights to reproduce and distribute the article (e.g. reprints), as well as all translation rights. No material published in this journal may be reproduced photographically or stored on microfilm, in electronic data bases, video disks, etc. without written permission from the Publisher and the Editorin-Chief. Printed in Italy.

\section{Copyright $2008^{\circ}$ Editrice Kurtis s.r.l.}

\section{SUBMISSION OF MANUSCRIPTS}

Manuscripts submitted must contain a statement to the effect that all human studies have been reviewed by the appropriate ethics committee and have therefore been performed in accordance with the ethical standards Jaid down in appropriate version of the 1964 Declaration of Helsinki. It should also be stated clearly in the text that all persons gave their informed consent prior to the inclusion in the study. Details that might disclose the identity of the subjects under study should be omitted.

Reports of animal experiments must state that the "Principles of laboratory animal care" (NIH publication No. 85-23, revised 1985) were followed, as well as specific national laws where applicable.

The Editor reserves the right to reject manuscripts that do not comply with the above-mentioned requirements. The authors will be held responsible for false statements or for failure to fulfill the above-mentioned requirements.

\section{Note to readers}

If products, dosages and methods of employment appear in this publication, the Publisher cannot grant their exactness and suggests that the reader should personally refer to the pertinent literature.

Manuscripts and all other editorial correspondence should be addressed to:

Massimo Cuzzolaro, M.D.

Editor-in-Chief

Via Savoia 72

00198 Roma, Italy

Tel. 39068541180

Fax 39068548363

e-mail: massimo.cuzzolaro@fastwebnet.it

\section{CALL FOR PAPERS}

Scientists from all over the world are kindly invited by the Editor and Publisher to send their contributions to the journal.

PRIVACY POLICY
Manual and electronic handling and processing of personal data necessary for the shipping
of this journal and other medical-scientific material is managed in compliance with Italian
law 196/03, Art. 13. The data processing is also compliant with Italian law 196/03, Art. 11.
The Publisher may disclose the personal data to business partners involved in the shipping
of the copy of this journal. The data processing rights are held by Editrice Kurtis, via Luigi
Zoja 30, 20153 Milano, Italy, to whom the readers may request at any time to update, inte-
grate, cancel their data or perform any other operation foreseen by ltalian law 196/03, Art. 7 .




\section{CONTENTS OF VOLUME 13, No. 3, 2008}

\section{PRINT' CONTENTS}

Original Research Papers

111 M.C. Escoto Ponce de León, J.M. Mancilla Diaz, and E.J. Camacho Ruiz A pilot study of the clinical and statistical significance of a program to reduce eating disorder risk factors in children

119 T. Yanover, and W.P. Sacco

Eating beyond satiety and body mass index

129 B. Roth, S. Munsch, A. Meyer, E. Isler; and S. Schneider The association between mothers ' psychopathology, childrens' competences and psychological well-being in obese children

137 D. Hambrook, and K. Tchanturia

A pilot study exploring Machiavellianism in anorexia nervosa

142 G.M. Ruggiero, S. Bertelli, L. Boccalari, F. Centorame, A. Ditucci, C. La Mela, A. Scarinci, P. Vinai, S. Scarone, and S. Sassaroli

The influence of stress on the relationship between cognitive variables and measures of eating disorders in healthy female university students: A quasi-experimental study

149 Z. Tao, and W. Zhong

The correlation of Chinese mothers' eating attitudes and psychological characteristics with their children's eating attitudes, as well as the gender effect on eating attitudes of children

\section{ELECTRONIC CONTENTS}

Proceedings of the Symposium "Advancements in Neuroendocrine and Autonomic Control of Metabolic Functions and their Pathological Significance" Verona, Italy, September 27, 2007

e40 A. Bartolomucci, A. Moles, and E. E. Müller Advancements in neuroendocrine and autonomic control of metabolic functions and their pathological significance

e42 S. Gaetani, W.H. Kaye, V. Cuomo, and D. Piomelli Role of endocannabinoids and their analogues in obesity and eating disorders

e49 A. Bartolomucci, A. Moles, A. Levi, and R. Possenti Pathophysiological role of TLQP-21: Gastrointestinal and metabolic functions

e55 R. Coccurello, F.R. D'Amato, and A. Moles Chronic administration of olanzapine affects Behavioural Satiety Sequence and feeding behaviour in female mice

e61 E.E. Müller Neuroendocrine and autonomic control of metabolic functions: Recent advances

e67 E. Bresciani, L. Tamiazzo, A. Torsello, I. Bulgarelli, D. Rapetti, S. Caporali, D. Perrissoud, A. Moulin, J.-A. Fehrentz, J. Martinez, and V. Locatelli Ghrelin control of GH secretion and feeding behaviour: The role of the GHS-R1a receptor studied in vivo and in vitro using novel non-peptide ligands 


\section{BUSINESS INFORMATION}

\section{PUBLISHING \\ DIVISION}

Chief Executive Officer

Canzio Fusé (Milano)

Editorial uffice Coordinator

Alessia Fusé (Milano)

ISSN online 1590-1262ISSN print 1124-4909

\section{BUSINESS}

\section{MATTERS}

One year personal subscription: print + online $€ 70,00$ (shipping charges outside ltaly: $€ 14,00$ ). One-year online subscription: $€ 45,00$. One year subscription for Institutions: print + online $€ 120,00$ (shipping charges outside Italy: $€ 14,00$ ). Price for single issue: $€ 20,00$ (personal) $€ 25,00$ (Institutional) (shipping charges outside Italy: $€ 3,50$ ). Changes of address: Allow six weeks for all changes to become effective.

All communications should include both old and new addresses (with postal codes) and should be accompanied by a mailing label from a recent issue. Claims are accepted and journals replaced on condition that subscription department is notified of non receipt within 3 months of issue date.

All business matters, inciuding correspondence and remittances relating to subscriptions, reprints and advertising should be sent to:

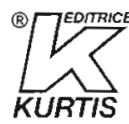

Editrice Kurtis s.r.l.

Via Luigi Zoja, 30

20153 Milano, Italy

Tel. 390248202740

Fax 390248201219

Internet: http://www.kurtis.it

E-mail: info@kurtis.it

Editrice Kurtis also publishes the following journals: Aggiornamento Medico - Aging Clinical and Experimental Research - Annali dell' Istituto Superiore di Sanità - i] Cardiologo - il Ginecologo - Ipertensione e prevenzione cardiovascolare - Journal of Enducrinologicul Investigation - I'Endocrinologo - Obesity and Metabolism - Sindrome Metabolica c Malattie Cardiovascolari - Urodinamica

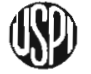

Associato all'USPi

Unione Stampa

Periodica Itäliana

Pubblicazione trimestrale a cura di:

Editrice Kurtis s.r.1.

Via Luigi Zoja 30

20153 Milano, Italy

Tel. 390248202740 - Telefux 390248201219

Internet: bttp://www.kurtis.it - E-mail: info@kurtis.it

Direttore responsabile: Canzio Fusé

Autorizzazione n. 263 del Tribunale di Milano del 22/4/1996.

ROC (Registro Operatori Comunicazione) n. 6133
CONFINDUSTRIA

\section{A.N.E.S \\ Associato all'ANES \\ Associazione Nazionale Editoria Specializzata}

Please fill in this form and send it to: Editrice Kurtis s.r.l. - Via Luigi Zoja 30, 20153 Milano, Italy, or fax to 390248201219.

Please enter my subscription to "Eating and Weight Disorders/Studies on Anorexia, Bulimia and Obesity"

[] One-year personal subscription: Print + online $€ 70,00$ (shipping charges outside Italy: $€ 14,00$ )

[] One-year online subscription: $€ 45,00$

$\square$ One-year subscription for Institutions: Print + online $€ 120,00$ (shipping charges outside Italy: $€ 14,00$ )

Methods of payment:

[ $]$ Postal payment C.C.P. 13282207

[.] Cheque $n$.

$\square$ Credit Card: $\square$ CartaSi $\square$ Visa $\square$ Eurocard $\square$ Mastercard
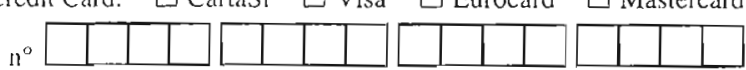

Date of birth

Stampa: Arti Grafiche Istaco s.r.l.

Uffici: Via Luigi Zoja 30, 20153 Milano

Tel. 390240910064

Stabilimento: Via Arluno 4, 20010 Casorezzo (MV)

Tel. $39029010415 / 16$ - Telefax 390290296747

Spedizione in abbonamento postale. Pubblicità inferiore al $45 \%$. A norma dell'aticolo 74 lettera c del DPR 26 otlobre 1972 n. 633 c del DM 28 dicembre 1972 il pagamento dell'IVA, assolto dall'Editore, è compreso nel pre\%zo dell'abbonamento o dei fascicoli separati. Non verrà rilasciata fattura se non su specifica richicsta.

Finito di stanpare nel mese di ottobre 2008.

Exp. Date

(Payable to Editrice Kurtis)

Send journals to:

Name

Address

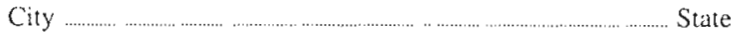

Zip

Phone

Fax

E-mail

$\checkmark A T$ registration numbel

P. IVA/C. Fisciale

Date

Signature

EU members please specify your VAT registration number. Lalian Subscribers: IVA paid by the Publisher.

Privacy Policy. Manual and clectronic handling and processing of personal data necessary for the shipping of this journal and other medical-scientific material is managed in compliance with Italian law 196/03, Art. 13. The data processing is also compliant with Italian law 196/03, Art. II. The Publisher may disclose the personal dat $w$ business partsers involved in the shipping of the copy of this journal. The data processing rights are held by Editrice Kurtis. via Luigi Zoja 30,20153 Milano, Italy, to whom the readers may request at any time to update, integrate, cancel their datil or perforn any other operation forescen by ltalian law $196 / 03$. Art. 7 .

$\square$ Please tick the box should you nol wish to receive further communications from Editrice Kurtis (Law 196/03). Signature. 


\title{
ORIGINAL A pilot study of the clinical and PAPER statistical significance of a program to reduce eating disorder risk factors in children
}

\author{
M.C. Escoto Ponce de León*. J.M. Mancilla Diaz**, and E.J. Camacho Ruiz***

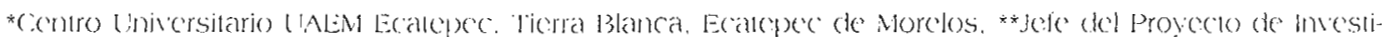 \\ gación on Nutrición. Faculad de Estubios Superiores kacala. Universidad Nacional Autónoma de México.

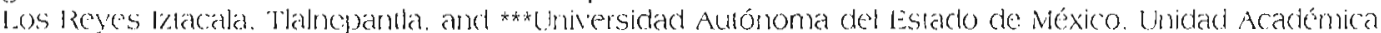

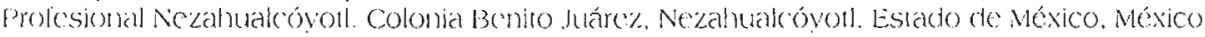

\begin{abstract}
The current study used clinical and statistical significance tests to investigate the effects of two forms (didactic or interactive) of a universal prevention program on attitudes about shape and weight, eating behaviors, the influence of body aesthetic models, and self-esteem. Three schools were randomly assigned to one, interactive, didactic, or a control condition. Children (61 girls and 59 boys, age 9-11 years) were evaluated at pre-intervention, post-intervention, and at 6-month follow-up. Programs comprised eight, 90-min sessions. Statistical and clinical significance tests showed more changes in boys and girls with the interactive program versus the didactic intervention and control groups. The findings support the use of interactive programs that highlight identified risk factors and construction of identity based on positive traits distinct to physical appearance.

(Eating Weight Disord. 13: 111-118, 2008). (2008, Editrice Kurtis
\end{abstract}

\section{INTRODUCTION}

There is consensus that eating disorders are multifactorial and reflect the accumulative effect of multiple genetic, psychological, familial, and sociocultural risk factors (1). Prevention of eating disorders involves an intervention that can interrupt accumulation of these factors, decreasing the likelihood of developing an eating disorder. The modifiable risk factors include diet, negative body image (2), low self-esteem (3), thinness idealization (4), drive for thinness, avoidance of fatty foods (5), and body dissatisfaction (6).

It has been suggested that men and their evaluation, should be included in eating disorder prevention programs, because they are part of the social environment that creates and maintains unhealthy diet norms and exerts pressure for thinness (7). Additionally, males comprise $9-10 \%$ of the eating disordered population $(8,9)$. However, few universal prevention programs have included prepubertal adolescent males (10-12).

Didactic programs, which introduce information to participants using an expositive method, have achieved changes in participants' knowledge but not in attitudes or behaviors. However, changes in attitudes and unhealthy behaviors using interactive programs, which include discussion, guided discovery, cognitive techniques, and cognitive dissonance, have been accomplished (13).

Usually, the effectiveness of prevention programs has been evaluated using statistical significance tests. Comparisons between pre-post treatment data to determine whether a prevention program is responsible for change in functioning relative to a control or comparison group are common. Such tests evaluate the change in likelihood but do not evaluate the effectiveness of an intervention in terms of the number of participants for whom risk is reduced, that is, whether the results of the intervention are clinically significant. Jacobson et al. (14) proposed a method to evaluate and compare the clinical significance of treatments: the reliable change index. Moreover Kendall et al. (15), proposed an additional approach known as normative comparisons. The evaluation of clinical significance represents an important proceed in the assessment of therapy outcome research, which extends to prevention as well (16).

The purpose of this study was to use clini- 
cal and statistical tests of significance to evaluate the effects of two forms (didactic or interactive) of a universal eating disorders prevention program for fifth-grade boys and girls. We hypothesized that the interactive program would decrease inappropriate attitudes and behaviors, related to feeding, body shape, and weight, and increase self-esteem in comparison to didactic program and a control condition.

\section{METHOD}

\section{Participants}

The sample 61 girls and 59 boys; age 9-11 years, $M=9.93, S D=0.44$ ) was recruited from three elementary public schools in the northern part of Mexico City. The three schools had three classes of fifth graders. In each school, one of three classes was randomly assigned to each condition. First school received interactive program (21 girls and 20 boys); second school received didactic program (19 girls and 21 boys); and last school was the control condition (21 girls and 18 boys). The study started at the beginning of the school year, and the attrition rate was $0 \%$ at post-intervention and follow-up.

\section{Intervention}

The intervention comprised the application of the body image program designed and published previously (17). This program is based on Social Cognitive Theory (SCT), which states that behaviour is influenced by the interaction between cognitive and emotional processes within the person. Within the eating disorder literature, particular attention is given to the sociocultural factors that create or maintain disordered eating. The focus of SCT-driven prevention programs is on decreasing risk factors associated with disordered eating (using cognitive-behavioural techniques), while also nurturing protective factors (18). From this perspective, the program focuses on changes of adolescence, sociocultural pressures for thinness, coping to adverse comments about weight and shape, dissatisfaction with body shape, self-esteem, and healthy eating. The program includes eight units, each one delivered in a 90-min weekly session. There were two versions of the intervention. In the interactive version, extensive use of discussion, guided discovery, role-play, guided meditation, and free-write exercises was made. The didactic version offered the same topics and contents using a primarily didactic expositive approach and included questionnaires, analysis, discussion, and homework (Appendix 1). The first author administered the interventions.

\section{Measures}

Eating disorder symptoms

The Children's Eating Attitudes Test (ChEAT) (19) was used to assess eating disorder symptoms. This 26 -item test is a well-established scale designed to assess maladaptative or problematic attitudes and behaviors among children $(19,20)$. Each item is rated on a Likert scale from 1 (always) to 6 (never), and for each question, the most symptomatic response is recoded to score of 3 , the next to 2 , and the next to 1 . The next choices receive a score of 0 , so ChEAT' scores range from 0 to 78. Maloney et al. (19) found an adequate test-retest reliability (0.81) and internal reliability (0.76) for a sample of 3rd-6rd graders. Smolak et al. (20) also found adequate internal reliability (0.87) and demonstrated an acceptable concurrent validity. A ChEAT's Spanish version showed internal reliability and concurrent validity acceptable for a Mexican sample (21). To assess eating disorder symptoms, ChEAT's total score was used. Cronbach's alpha for the present study was 0.82 .

\section{Body dissatisfaction}

Total score on Body Shape Questionnaire (BSQ) was used to assess body dissatisfaction (22). Each item is rated on a Likert scale from 1 (never) to 6 (always), and for each question, the most symptomatic response is recoded to score of 6 , so $\mathrm{BSQ}^{\prime}$ scores range from 34 to 204. Higher BSQ scores reflect greater body shape dissatisfaction. This 34 -item test was adapted for the Spanish population (23), and it has been used with 12-year (24) and 10-year Mexican children (5). BSQ has a Cronbach's alpha of 0.98 for México (25) and 0.97 for Spain (26). Internal consistency in this study was 0.93 .

\section{Overeating}

The Bulimia Test's (BULIT) (27) Overeating Subscale proposed by Álvarez et al. (28) was used. Cronbach's alpha for the present study was 0.85 for this subscale.

\section{Influence of body aesthetic models}

The Influence of the Body Aesthetic Models Questionnaire (CIMEC) (29) is a 40 -item instrument. Each item is rated on a Likert scale from 1 to 3 , so CIMEC' scores range from 40 to 120 , and higher scores reflect greater influence of the models. CIMEC has been used in Mexican children with a mean age of 10 years (5), and adolescents from 11 to 18 years (30). The alpha reliability coefficient of 0.94 indicates that the CIMEC has satisfactory internal consistency in a sample of 14 to 33-year females (5). We used the total score, and Cronbach's alpha for the present study was 0.92 . 
Self-esteem

The Children's Self-Esteem Inventory (PAI) (31) evaluates one's self-perception and ideal. The 21-item inventory was validated in Mexico by Caso (32), who found a good reliability $(\alpha=0.82)$. In this study, we used the total score, with a Cronbach's alpha of 0.84 .

\section{Procedure}

Before beginning of the study, children and their parents were informed of nature of program and provided signed consent to participate and allow anonymous use of data. All participants completed the instruments as part of the class curriculum in three times: Before the intervention, 1 week after completing the intervention, and at a 6-month follow-up. Children were asked to provide sociodemographic data required for the study at the first time point only. The instructions for each instrument were read aloud to participants. Once everyone understood how to answer the questions using a Likert scale, the researcher read and slowly repeated each question in the scale. Each participant received a white sheet of paper as a guide to identify the line corresponding to each question. At the end of each page, they were asked to check that they had answered all the questions and then, to continue reading on the following page. Each questionnaire was administered in a session in the next order: ChEAT, CIMEC, BSQ, PAI, and the BULIT Overeating subscale. The same procedure was used in pre-intervention, post-intervention, and at follow-up.

The interventions were delivered 1 week after participants first completed the instruments, in presence of the children's teacher. We asked teachers not to discuss the content of the program in between sessions or after finishing it. To prevent communication between participants, a different school for each condition was selected.

\section{Data analysis}

SPSS 10.0 was used for statistical analyses. To determine if participants in the intervention programs experienced reductions over time in comparison to control group, repeated measures ANOVA were applied to each dependent variable (self-esteem, body dissatisfaction, overeating, influence of body aesthetic models, and ED symptoms) using the within-subjects factor time (pre-intervention, post-intervention, and follow-up) and the between-subjects factor condition (interactive, didactic, and control). The Bonferroni test $(p<0.05)$ for post hoc comparisons was used. Power analysis was performed using G*Power Software (33).

The clinical significance of change was examined in two ways. First, we calculated the Reli- able Change Index (RCI) (14); a $\mathrm{RCI}>1.96$ indicates that the change was due to a nonrandom treatment effect, with 95\% reliability. Second, we performed normative comparisons of treatment effects using the procedures proposed by Kendall et al. (15). Normalive comparisons included only those participants who surpassed ChEAT's cut-off (score $\geq 15$ ) (19) at pre-intervention.

\section{RESULTS}

\section{Preliminary analysis}

One-way ANOVA at pre-intervention indicated no significant group differences $(p>0.05)$ in age, nutritional index, body dissatisfaction, overeating, the influence of body aesthetic models, and self-esteem scores for girls and boys, separately.

\section{Statistically significant changes}

Table 1 shows participants' mean scores on dependent measures at the three times. There were no gender effects on any variable at postintervention or follow-up ( $p>0.05$ ).

\section{Changes in cirls}

For body dissatisfaction scores, there were main effects of group, $F(2,58)=7.51, p=0.001$ only. There was a small decrease in body dissatisfaction scores from pre-intervention to post-intervention and follow-up for the interactive group, while there was no change in scores for didactic and control groups.

For overeating scores, there were main effects of group, $F(2,58)=3.39, p=0.04$, only. Overeating scores decreased from pre-intervention to follow-up in the interactive group but did not reach significance. There were no changes for the didactic and control groups.

A main effect of Time $x$ Group interaction, $F(2,58)=2.71, p=0.03$, was observed for the influence of body aesthetic models. In the interactive group, there was a significant decrease in the scores from pre-intervention to followup, while there were no changes for didactic and control groups.

For self-esteem, there were main effects of group, $F(2,58)=4.03, p=0.02$, and Time $x$ Group interaction, $F(2,58)=7.60, p=0.001$. However, scores did not reach significance for the interactive and didactic groups.

For ChEAT' scores, there were main effects of group, $F(2,58)=5.66, p=0.006$ only. Scores decreased from pre-intervention to post-intervention and follow-up in the interactive group but did not reach significance. There were no changes for the didactic and control groups. 
TABLE I

Mean scares of groups on pre-treatment, post-treatment, and follow-up.

Scale/

group

Body dissatisfaction

Interactive

Didactic

Control

Overeating

Interactive

Didactic

Control

Body aesthetic models influence Interactive

Didactic

Control

Self-esteem

Interactive

Didactic

Control

Eating disorder symptoms

Interactive

Didactic

Control

$\begin{array}{cc} & \\ & \text { Time } \\ \text { Pre } & \text { Posi } \\ \text { (EE) } & M \\ & \text { (EE) }\end{array}$

Boys

$\begin{array}{lll}73.15 & 55.70 \quad 55.90\end{array}$

(6.84)

73.19

(7.21)

76.56

$(7.17)$

21.50

$(1.91)^{\circ}$

19.43

$(1.30)$

20.11

(1.50)

18.95

$(1.47)^{\circ}$

19.20

(3.81)

17.57

(3.68)

16.00

(2.49)

\section{$54.05 a$}

(1.53)

54.10

(1. .501

55. 11

(1.94)

55.25

(1.62)

52.62

11.75
$(2.27)$
9.43
$(1.72)$
11.28
$(2.56)$

(5.14)

60.00

[5.47)

71.72

(7.27)

21.38

(2.03)

17.33

$\{1.21\}$

14.35

(3.96)

15.24

(2.86)

18.50

(3.23)

(1.79)

53.61

(2.03)

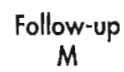

(EE)

55.90

(4.23)

62.24

(4.98)

6989

(8.09)

15.00
$(0.98$

16.52

(0.99)

21.11

(1.18)

10.85

(2.44)

8.90

(2.10)

14.33

(2.82)

59.50
$(0.78)$
57.29
$(1.31)$
56.78
$(1.50)$

9.40

(2.14)

10.29

\{1.96\}

7.28

(2.82)
5.30

(1.18)

5.95

\{2.16\}

7.44

(2.12)

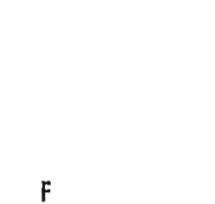

$\stackrel{\text { Pre }}{M}$

$3.31^{*}$

1.40

0.21

58.67

(5.63)

75.84

(5.74)

73.33

(6.05)

$4.75^{*}$

2.65

2.25

17.14

(1.16)

19.58

$(1.40)$

19.76

(1.27)

3.46

15.29

(4.02)

21.42

2.30

(3.55)

14.33

\{2.21\}

$4.42^{*}$

60.10

10.98\}

2.39

54.95

(1.63)

0.74

55.10

(1.25)

2.88

1.38

7.24
$11.26)$
8.79
$(2.28]$
11.76
$(2.04)$

0.81
Girls

Time

Post
M)
(EE)

Follow-up

$M$

(EE)

F

$\begin{array}{lll}45.67 & 47.43 & 3.27^{\circ} \\ (2.72) & (2.54) & \\ 66.53 & 69.00 & 0.67 \\ (6.72) & (5.11) & \\ 74.24 & 75.33 & 0.02 \\ \mid 6.77) & (7.45) & \end{array}$

1.57

0.87

0.63

(1.55)

(1.16)

$9.9 \quad 7.05$

(2.78) [1.14!

$16.32 \quad 18.58$

(2.85) (4.12)

$19.05 \quad 17.29$

$\{2.92\} \quad\{2.94\}$

$\begin{array}{ll}56.67 & 60.69 \\ (1.83) & (0.77) \\ 54.84 & 58.68 \\ (1.67) & (1.08) \\ 54.05 & 56.38 \\ (1.62) & (1.33)\end{array}$

4.81
$\{1.32\}$
10.32
$(2.88)$
15.57
$(2.38)$

4.43

$10.97\}$

6.84

(1.83)

11.43

[2.04]
3.09

2.17

0.69

2.09

0.52

0.77

$M=$ mean; $S E=$ standard error. Means within the same row with different subscripts were statistically significantly different ( $<<0.05)$. "p<0.05, " $p<0.01, \cdots p<0.001$

\section{Changes in boys}

For body dissatisfaction scores, there were main effects of time, $F(2,56)=9.15, p=0.0001$ only. There was a decrease in body dissatisfaction scores from pre-intervention to post-intervention and follow-up for the interactive group, while there was no change in scores for didactic and control groups.

For overeating scores, there were main effects of group, $F(2,56)=5.09, p=0.01$, and Time $x$ Group interaction, $F(2,56)=6.07$, $p=0.0001$. There was a significant decrease from pre-intervention to follow-up in the interactive group. There were no changes for didactic and control groups.
A main effect of time, $F(2,56)=8.14, p=0.001$, was observed for the influence of body aesthetic models. Both, in the interactive and didactic group, there were a decrease in the scores from pre-intervention to post-intervention and follow-up however did not reached significance.

For self-esteem, there were main effects of time, $F(2,56)=9.18, p=0.0001$ only. Scores significantly increased from pre-intervention to follow-up for interactive group.

For ChEAT' scores, there were main effects of group, $F(2,56)=5.66, p=0.006$ only. Scores decreased from pre-intervention to post-intervention and follow-up in the interactive group 
but did not reach significance. There were no changes for didactic and control groups.

Clinically significant changes

Reliable change index (RCI)

Table 2 indicates the percentage of subjects who showed a positive change, above a RCI of 1.96 at post-intervention or follow-up. Deterioration effect was not found in any cases. A number of relatively higher positive RCI percentages were found for intervention groups in comparison to control. In contrast, no cases in control group showed reliable change fomitted data). Boys in interactive group showed reliable change on all variables whereas in didactic group improvement was found in all scales except for overeating. Changes in girls were almost the same in all scales, except for overeating and ED symptoms.

\section{Normative comparisons}

Normative comparisons of the effects of treatments were made for participants who surpassed ChEAT's cut-point. In girls interactive intervention promoted significant clinically changes in scores on all scales, whereas didactic intervention promoted changes in self-esteem only. In boys, both interactive and didactic intervention promoted changes in all scales except in eating disorders symptoms. In all cases, changes were maintained to follow-up. It is important to establish that there were no wrong outcomes.

\section{TABLE 2}

Participants that showed an improvement (Reliable Change Index $>1.96$ ) from pre-treatment to post-treatment and pre-treatment to follow-up.

\begin{tabular}{|c|c|c|c|c|}
\hline \multirow[b]{2}{*}{ Scale } & \multicolumn{2}{|c|}{$\begin{array}{c}\text { Interactive } \\
\% \text { participants }\end{array}$} & \multicolumn{2}{|c|}{$\begin{array}{c}\text { Didactic } \\
\text { \% participants }\end{array}$} \\
\hline & $\begin{array}{c}\text { Girls } \\
(n=2])\end{array}$ & $\begin{array}{l}\text { Boys } \\
(n=20)\end{array}$ & $\begin{array}{c}\text { Girls } \\
\langle n=19\rangle\end{array}$ & $\begin{array}{l}\text { Boys } \\
\{n=21\}\end{array}$ \\
\hline $\begin{array}{l}\text { Body dissatisfaction } \\
\text { Post } \\
\text { Follow-up }\end{array}$ & $\begin{array}{l}19.05 \\
9.52\end{array}$ & $\begin{array}{l}40.00 \\
40.00\end{array}$ & $\begin{array}{l}26.32 \\
26.32\end{array}$ & $\begin{array}{l}23.81 \\
19.05\end{array}$ \\
\hline $\begin{array}{l}\text { Overeating } \\
\text { Post } \\
\text { Follow-up }\end{array}$ & $\begin{array}{l}0.00 \\
4.76\end{array}$ & $\begin{array}{l}10.00 \\
25.00\end{array}$ & $\begin{array}{l}0.00 \\
10.53\end{array}$ & $\begin{array}{l}4.76 \\
9.52\end{array}$ \\
\hline $\begin{array}{l}\text { Body aesthetic models influence } \\
\text { Post } \\
\text { Follow-up }\end{array}$ & $\begin{array}{l}14.29 \\
23.81\end{array}$ & $\begin{array}{l}15.00 \\
35.00\end{array}$ & $\begin{array}{l}26.32 \\
26.32\end{array}$ & $\begin{array}{l}14.29 \\
38.10\end{array}$ \\
\hline $\begin{array}{l}\text { Self-esteem } \\
\text { Post } \\
\text { Follow-up }\end{array}$ & $\begin{array}{l}9.52 \\
14.29\end{array}$ & $\begin{array}{l}40.00 \\
50.00\end{array}$ & $\begin{array}{l}31.58 \\
52.63\end{array}$ & $\begin{array}{l}19.05 \\
47.62\end{array}$ \\
\hline $\begin{array}{l}\text { ED symptoms } \\
\text { Post } \\
\text { Follow-up }\end{array}$ & $\begin{array}{l}4.76 \\
9.52\end{array}$ & $\begin{array}{l}15.00 \\
20.00\end{array}$ & $\begin{array}{l}5.26 \\
10.53\end{array}$ & $\begin{array}{c}4.76 \\
23.81\end{array}$ \\
\hline
\end{tabular}

Note: Improvement in control group was $0 \%$ in all variables.

\section{DISCUSSION}

This study focused on development, implementation, and evaluation of a universal eating disorder prevention program for fifth-grade boys and girls in a school environment. Participants reported decreases in scores on overeating and influence of body aesthetic models. These results are consistent with those for focused prevention aimed at adolescent women (34-36) and partially support the idea that interactive programs, emphasizing social competences and instruction of social ability, promote more changes than do didactic programs emphasizing transmission of information (13). We did observe some changes in behaviors of boys and girls in didactic group. This can be explained by the program content and the inclusion of tasks such as questionnaires, interviews, and reflections, which probably promoted self-reflection.

Tests of clinical significance determined that the most widespread improvement occurred in the interactive group. These changes are attributable to intervention, which in the literature has been shown to decrease identified risk factors, including social idealization of thinness, which leads to body dissatisfaction and recurrent restrictive dieting to lose weight (37).

Of the participants with eating disorder symptoms before the intervention, a higher percentage of girls in the interactive group than in the didactic group showed improvement. These results are in accordance with those reported by Stice et al. (13), who found that interactive interventions promoted more changes than did didactic interventions. It is relevant to point out that equivalence tests indicated that the scales had sufficient statistical power to determine the effectiveness of the interventions.

We did not find evidence of harmful effects of the interventions (38). Our results are attributable to the fact that program content did not include information about eating disorders or methods for weight control.

Previous studies on eating disorder programs, evaluated the effects of only one modality, interactive or didactic. Thus, our study makes an important contribution in this sense. In addition, our participants were boys and girls aged 9-11 years, and our goal was to establish an authentic scenario in order to reflect the natural social environment of children, because the literature indicates that men are part of a subculture that supports the idealization of thinness (7).

Our results support the idea that lessons directed to develop a sense of identity based on 
competencies rather than physical appearance, increase self-esteem by confronting participants with idea that it is necessary to be slender to achieve health, success, and good interpersonal relationships. This may have a positive effect on the unhealthy and unreal attitudes that culture promotes.

The sample size was small, so results should be interpreted with caution. Because the groups were small, random assignment is of limited utility. However, statistical power was between 0.59 and 1.00 for all scales except selfesteem, where it was 0.24

In future investigations, it is important that in addition to self-report questionnaires, also blind diagnostic interviews be used to evaluate eating disorder symptoms, because they offer a more precise evaluation. It is necessary to replicate the study with a larger sample size including students from both, public and private schools. This would increase the statistical power and generalizability. In addition, it will be important to conduct investigations with a longer follow-up, in order to verify if effects continue.

The two programs were administered by the author of the study. Unfortunately, the design of the study did not include any instrument to evaluate the fidelity of the program administration (e.g., to record the intervention and to have a blind supervisor that evaluate the recorded prevention sessions).
Unit/Content

\section{Program Introduction. Interpersonal relationships.}

\section{Positive self-affirmations. Qualities unrelated to appearance.}

III. Changes in adolescence. Prejudices about shape and weight. Fat myths.

\section{Assertiveness in situations related to shape and weight.}

\section{$V$. Resistance to sociocultural pressures for thinness.}

\section{APPENDIX 1. Activities used in programs. (cont).}

Activities/techniques

\section{Interactive}

Modeling, role-play with verbal self-instruction, feedback, and reinforcement: Dealing with others. Free-writing: Interpersonal feelings. Homework: Start a conversation with a neighbor and a partner of another group.

Modeling, role-play with verbal self-instruction, feedback, and reinforcement: positive self-affirmations. Homework: Identify qualities of oneself unrelated to appearance, increasing every day a positive thing.

Guided discovery: Changes in adolescence. Cognitive restructuring and feedback: Prejudices about obese and thin people using clips from magazines. Homework: Elaborate a family album, commenting on changes that have happened in their lives.

Role-play and partners as tutors that model (using verbal self-instruction) assertive, passive, and aggressive answers to sociocultural pressure toward shape and weight.

Free-writing: Overweight.

Homework: Approach somebody whom you judged for their aspect and write how he/she really is. Do not include aspects of his/her appearance.

Comparing personal values vs. media values that magazines promote. Modeling and role-play: Resistance to media messages.

Role-play using verbal self-instruction: Teasing

Homework: Disagreement letter about magazine messages.

Record eating habits.

\section{Didactic}

Script information, brainstorm, reading and free-writing: Interpersonal relationships.

Homework: Same as interactive.

Script information, brainstorm, and free-writing.

Scramble: Self-affirmations.

Homework: Same as interactive.

Script information, reading, brainstorm, and free-writing: Changes observed in partners or familial adolescents, prejudices about shape and weight, and fat myths.

Homework: Same as interactive.

Script information, discussion, reading, and scramble: Assertive, passive, and aggressive answers.

Free-writing: Overweight.

Homework: same as interactive.

Script information and free-writing:

Media messages and values.

Brainstorm: Magazine content.

Case study: Teasing

Homework: Same as interactive. 


\section{APPENDIX 1. \\ Activities used in programs}

Unit/Content

VI. Healthy feeding.
VIII. Healthy relationships. Conflict solving.

\section{Interactive}

Food classification.

Menu preparation.

Compare preferred foods (record) to nutritional pyramid.

Homework: Interview the person that prepares meals at home; ask about healthy foods that he/she included in the menu.

Description of situations where they have felt different emotions and how to respond to them.

Role-play with reinforcement and feedback: Expression of different emotions.

Guided meditation: Management of emotions.

Homework: Ask other people in which body part they feel different emotions.

Elaboration of a social constellation. Identification of interpersonal problems. Role-play with expression of emotions and feelings related to interpersonal problems.

Closure: Agreement to apply what was learned.

\section{Didactic}

Script information, brainstorm and scramble: Healthy/unhealthy feeding. Questionnaire: Feeding preferences. Homework: Same as interactive.

Script information: Appropriate expression of emotions.

Reading, case study and free-writing: Emotional hunger and ways to answer to it. Homework: Same as interactive.

Script information, case reading, and free-writing.

Closure: Same as interactive.

\section{ACKNOWLEDGEMENTS}

Grant sponsors: UAEM 1914/2004-2 and 2343/06; PAPIT IN304606; CONACyT 50305-H.

\section{REFERENCES}

1. Striegel-Moore R., Steiner-Adair C.: Prevención primaria de los trastornos alimentarios: nuevas consideraciones con una perspectiva feminista. In: Vandereycken W., Noordenbos G. (Eds.), La Prevención de los Trastornos Alimentarios. España, Granica, 2000, pp. 13-37.

2. Noordenbos G.: Los trastornos alimentarios en lá atención primaria de la salud: la identificación e intervención temprana de parte de los médicos clínicos. In: Vandereycken W., Noordenbos G. (Eds.), La Prevención de los Trastornos Alimentarios. España, Granica, 2000, pp. 261-277

3. Fairburn G., Welch L., Doll A., Davies A., O'Connor E.: Risk factors for bulimia nervosa. A communitybased case-control study. Arch. Gen. Psychiatry, 54, 509-517, 1997.

4. Levine M., Smolak L.: Los medios de comunicación y los disturbios de la alimentación: Consecuencias en la prevención primaria. In: Vandereycken W., Noordenbos G. (Eds.), La Prevención de los Trastornos Alimentarios. España, Granica, 2000, pp. 39-80.

5. Várquez R., López X., Álvarez G., Mancilla J., Ruiz A.: Insatisfacción corporal e influencia de los modelos estéti$\cos$ en niños y jóvenes varones mexicanos. Enseñanza e
Investigación en Psicología, 11, 185-197, 2006.

6. Gómez-Peresmitré G.: Preadolescentes mexicanas y la cuitura de la delgadez. Revista Mexicana de Psicologia, 16, 153-165, 1999.

7. Austin B.: Prevention research in eating disorders Theory and new directions. Psychol. Med., 30, 1249 1262, 2000.

8. American Psychiatric Association. Diagnostic and Statistical Manual of Mental Disorders, 4th ed. Revised (DSM-IV-TR). Washington, D.C., APA, 2000.

9. Hoek H.W., Bartelds A.I., Bosveld J.J, van der Graaf Y., Limpels V.E., Maiwald M., Spaaij C.J.: Impact of urbanization on detection rates of eating disorder. Am. J. Psychiatry, 152, 1272-1278, 1995.

10. Smolak L., Levine M.P.: A two-year follow-up of a primary prevention program for negative body image and unhealthy weight regulation. Eat. Disord., 9, 313325,2001

11. Smolak L., Levine M.P., Schermer F.A.: A controlled evaluation of an elementary school primary prevention program for eating problems. J. Psychosom. Res., 44, 339-353, 1998.

12. Smolak L., Levine M.P., Schermer F.A.: Lo que nos enseñó la enseñanza: evaluación de un programa preventivo para las escuelas primarias. In: Vandereycken W., Noordenbos G. (Eds.), La Prevención de los Trastornos Alimentarios. España, Granica, 2000, pp. 173-213.

13. Stice E., Shaw H.: Eating disorder prevention programs: A metaanalytic review. Psychol. Bull, 130, 206$227,2004$.

14. Jacobson S., Truax P.: Clinical significance: A statistical approach to defining meaningful change in psy- 
chotherapy research. J. Consult. Clin. Psychol., 59, 1219, 1991.

15. Kendall P., Marrs-García A., Nath S., Sheldrick C.: Normative comparisons for the evaluation of clinical significance. J. Consult. C.in. Psychol., 67, 285-299, 1999.

16. Kazdin $A$.: The meanings and measurement of clinical significance. J. Consult. Clin. Psychol., 67, 332-339, 1999.

17. Escoto M.C., Mancilla J.M.: Prevención de Trastornos del Comportamiento Alimentario en Adolescentes. In: Rios M.R. (ed.). Manual de Intervención Psicológica para Adolescentes: Ámbito de la Salud y Educativo. Colombia. Psicom Editores, 2007.

18. Levine M.P., Smolak L.: (Eds.). The prevention of eating problems and eating disorders: Theory, research, and practice. Mahwah, NJ, Lawrence Erlbaum Associates, 2006.

19. Maloney M., McGuire B., Daniels R.: Reliability testing of the children's version of the Eating Attitudes Test. J. Am. Acad. Child. Adolesc. Psychiatry, 27, 541-543, 1988.

20. Smolak L., Levine M.: Psychometric properties of the Children's Eating Attitudes 'Test. Int. J. Eat. Disord., 16, 285-282, 1994.

21. Escoto M.C., Camacho E.J.: Psychometric properties of the Children's Eating Attitudes Test in a Mexican sample. Revista Mexicana de Psicología, 25, 99-106. 2008.

22. Cooper J., Taylor J., Cooper Z., Fairburn G.: The devejopment and validation of the body shape questionnaire. Int. J. Eat. Disord., 6, 485-494, 1987.

23. Raich R., Mora M., Soler A., Avila C., Clos I., Zapater L.: Adaptación de un instrumento de evaluación de la insatisfacción corporal. Clinica y Salud, 7, 51-66, 1996.

24. Beato-Fernández L., Rodríguez-Cano T., BelmonteLlario A., Martinez-Delgado C.: Risk factors for eating disorders in adolescents. Eur. Child Adolesc. Psychiatry, 13, 287-294, 2004.

25. Galán J.: Validación en población mexicana del Body Shape Questionnaire. Tesis de Licenciatura, Universidad Nacional Autónoma de México, 2004.

26. Espina A., Asunción O.M., Ochoa A.I., Aleman A., Juaniz $M$ : Body shape and eating disorders in a sample of students in the Basque country: A pilot study. Psychol. Spain, 6, 3-11, 2002.
27. Smith C., Thelen H.: Development and validation of a test for bulimia. J. Consult. Clin. Psychol., 52, 863-872, 1984.

28. Álvarez G., Mancilla-Diaz J., Vázquez R.: Propiedades psicométricas del Test de Bulimia (BULIT). Psicología Contemporánea, 7, 74-85, 2000.

29. Toro J., Salamero M., Martinez E.: Assessment of sociocultural influences on the aesthetic body shape model in anorexia nervosa. Acta Psychiatr. Scand., 89, $147-151,1994$

30. Toro J., Gomez-Peresmitrè G., Sentis J., Vailés A., Casulá V., Castro J., Pineda G., Leon R., Platas S., Rodriguez R.: Eating disorders and body image in Spanish and Mexican female adolescents. Soc. Psychiatry Psychiatr. Epidemiol., 41, 556-565, 2006.

31. Pope W., McHayle M., Craighead E.: Self-esteem enhancement with children and adolescents. USA, Allyn and Bacon (eds.), 1988.

32. Caso J.: Validación de un instrumento de autoestima para niños y adolescentes. Tesis de Maestría, Universidad Nacional Autónoma de México, 1999.

33. Faul F., Erdfelder E., Lang A.G., Buchner A.: G*Power 3: A flexible statistical power analysis program for the social, behavioral, and biomedical sciences. Behav. Res. Methods, 39, 175-191, 2007.

34. Matusek A., Wendt J., Wiseman V.: Dissonance thinideal and didactic healthy behavior eating disorder prevention programs: Results from a controlled trial. Int. J. Eat. Disord., 36, 376-388, 2004.

35. Stice E., Chase A., Stormer S., Appel A.: A randomized trial of a dissonance-based eating prevention program. Int. J. Eat. Disord., 29, 247-262, 2001.

36. Stice E., Ragan J.: A preliminary controlled evaluation of an eating disturbances psychoeducational intervention for college students. Int. J. Eat. Disord., 31, 159-171, 2002.

37. Álvare? G.: Modelos de factores predictores de trastornos del comportamiento alimentario en tres muestras de mujeres mexicanas. Tesis de Doctorado. Universidad Nacional Autónoma de México, 2006.

38. Mann T., Nolen-Hoeksema S., Huang K., Wright A., Hanson K., Burgard D.: Are two interventions worse than none? Joint primary and secondary prevention of eating disorders in college females. Health Psychol., 16, 215-225, 1997. 